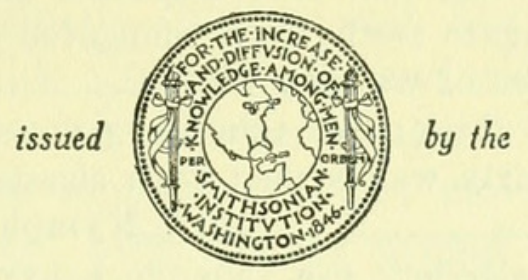

SMITHSONIAN INSTITUTION

U. S. NATIONAL MUSEUM

\title{
PYCNOGONIDS FROM PUGET SOUND
}

\author{
By Harriet I. Exuine
}

University of Washington, Seattle, Wash.

Prcnogonids are not commonly dredged in Puget Sound, Wash., but they are sometimes found in large numbers in certain rather isolated localities. ${ }^{1}$ In the waters around the San Juan Islands, which have been quite thoroughly investigated, probably only half a dozen specimens have been collected in the past 10 years. On the other hand, with the investigation of the waters south of the San Juans, especially in the vicinity of McNeils Island, pycnogonids have been collected in large numbers among the hydroids dredged from rocky bottoms.

This paper is a report upon five species of pycnogonids, three of which are new, collected in Puget Sound and neighboring waters on dredging expeditions of the University of Washington's research ship Catalyst. Thanks are due Prof. T. G. Thompson, director of the university's oceanographic laboratories, and to Profs. T. Kincaid, J. E. Guberlet, Robert C. Miller, and M. H. Hatch, of the university's zoology department, for assistance and cooperation given.

$$
\text { KEY TO PUGET SOUND SPECIES OF PYCNOGONIDS }{ }^{2}
$$

$a^{1}$. Cheliferi with well-developed chelae, which lie in front of mouth.

$b^{1}$. Palpi present; first segment bearing neck, from terminal part of which the paipi and cheliferi originate but which does not bear eye tubercle NYMPHONIDAE Hoek

1 Compare with Hodgson's (1907) introduction.

2 Compiled in part from Bouvier (1913) ; Cole (1904); Hall (1913); and Schimkewitsch (1913). 
Ten-segmented oviger in both male and female, provided with a terminal claw, and last four segments armed with an inner row of elongate teeth; body elongated and distinctly segmented; 4 pairs of walking legs

Nymphon Fabricius

$c^{1}$. Chelae short and thick; eye tubercle pointed and turretshaped; legs fairly well armed with slender spines (fig. $33, g-k)$ Nymphon turritum, new species

$c^{2}$. Chelae long and slender; eye tubercle heavy at base and with slender tip; legs almost naked (fig. 33, $a-d$ )

Nymphon solitarium, new species

$b^{2}$. Palpi absent; oviger present only in male and without terminal claw; body elongated, segmented; eye tubercle borne on anteriormost part of anterior segment ; 4 pairs of legs ; genital apertures in both male and female on all 4 legs

Phoxichelididdae Sars

Ovigera 5-segmented; first trunk segment not greatly produced in front above proboscis

(Phoxichilidium Edwards) P. femoratum (Rathke)

$a^{2}$. Cheliferi weakly developed, shorter than proboscis, not chelate in adult forms; palpi usually longer than proboscis; ovigera present in both sexes, 10 -segmented and without terminal claw ; 4 pairs of legs; genital openings in male on legs 3 and 4 , in female on all 4 pairs

Ammotheidae Dohrn

$b^{1}$. Cheliferi 2-segmented, palpi 8-segmented______________Ammothea Leach

$c^{1}$. Cheliferi half as long as proboscis; abdomen reaching only to second coxal segment of posterior legs or slightly beyond (fig. $33, e, f$ ) Ammothea discoidea, new species

$c^{2}$. Cheliferi less than half as long as proboscis; protuberance on dorsal side of first coxal segment half as long as segment, genital protuberance same length_-_Ammothea alaskensis Cole $b^{2}$. Cheliferi 3-segmented, palpi 9-segmented

(Ammothella Verrill) A. longicaudata (Stimpson)

\section{Genus NYMPHON Fabricius}

NYMPHON SOLITARIUM, new species

\section{Figure $33, a-d$}

Description.-Body slender, elongated, segmentation conspicuous, lateral processes widely separated, legs very long and slender. Trunk segments almost equal in thickness, except posterior segment, which is slenderer; segments of approximately same length, each thickest where lateral processes originate, a little behind middle of segment. Anterior segment bearing high eye tubercle dorsal to origins of ovigera, which are anterior to walking legs; eye tubercle heavy and abruptly pointed distally, with eyes large and basal, sometimes almost contiguous (in some specimens eyes hardly visible and may be rudimentary). Anterior segment in front of eye tubercle prolonged into neck, which is swollen anteriorly, bearing the cheliferi dorsally, palpi laterally, and proboscis anteroventrally. Proboscis 
cylindrical, slightly longer and much thicker than neck. Palpi with scape longer than second segment, slightly curved, almost as long as proboscis; second segment shorter and heavier than scape; both movable and immovable fingers long and slender and well-toothed on their inner margins. Immovable finger almost straight to distal part, which terminates in a curved tip; movable finger curved and longer than immovable; both fingers armed on their inner margin with teeth, some of which are almost contiguous at their bases, and all are pointed almost evenly to their apexes and somewhat curved.

Ovigera 10-segmented; first segment very short; second and third about equal and a little longer than the first; fourth about twice as long as first three together; fifth slenderer and longer than fourth, swollen at its distal end (it is this segment around which the eggs are carried in one or two closely packed masses); sixth segment, much shorter and armed with many short hairs on its ventral side; seventh shorter than sixth and closely beset on its ventral margin with an even row of about 13 elongated spines, which are armed laterally, these spines almost touching one another at their bases and about as long as the segment is thick; eighth a little shorter than seventh and armed as seventh; ninth and tenth about equal to seventh in length and similarly armed; these last three segments are definitely curved on their ventral margins and form a curved end to the oviger as a whole; the tenth segment bears a long well-developed claw, which is armed with ordinary teeth on its ventral margin, as are the fingers of the chelae.

Legs almost naked, about $37 \mathrm{~mm}$ long; first coxa $0.6 \mathrm{~mm}$, second $3 \mathrm{~mm}$, third $1.2 \mathrm{~mm}$, femur $7.2 \mathrm{~mm}$ and somewhat ventrally curved; first tibia $8.8 \mathrm{~mm}$, second tibia $11.4 \mathrm{~mm}$; first tarsus $2.6 \mathrm{~mm}$, second tarsus $1.3 \mathrm{~mm}$; claw $1 \mathrm{~mm}$, unarmed on its ventral margin; auxiliary claw present but only one-fourth as long as true claw.

Abdomen finger-shaped, very short, and articulated to body segment.

Measurements.-Body 6-7 mm. A specimen $6 \mathrm{~mm}$ long measures: Proboscis $2 \mathrm{~mm}$; neck $1.7 \mathrm{~mm}$; first segment $1 \mathrm{~mm}$; second segment $0.8 \mathrm{~mm}$; third segment $0.8 \mathrm{~mm}$; fourth segment $0.7 \mathrm{~mm}$; abdomen $0.6 \mathrm{~mm}$; second lateral process $0.7 \mathrm{~mm}$ long; eye tubercle $0.5 \mathrm{~mm}$ high.

Types.-Holotype: Male from Puget Sound collected May 7, 1933, U.S.N.M. no. 71496. Paratypes: 1 male carrying eggs collected half a mile southwest of Flat Point, San Juan County, from 30 meters, July 6, 1935; 1 specimen from Foulweather Bluff, February 25, 1934, from 50 to 80 meters; 1 specimen from Puget Sound (Professor Kincaid's collection); 1 specimen from Dougall Point (Pickering Pass), Puget Sound, May 6, 1933, from 16 fathoms. 
Remarks.-Nymphon solitarium is placed with those species of Nymphon that have auxiliary claws and in which the first tarsus is considerably longer than the second. Among the species noted by Bouvier (1913) and Hodgson (1907), N. solitarium most closely resembles $N$. meridionale and $N$. hiemale. It is separated from these by the fact that the scape of the chelicera is shorter than the proboscis. See Bouvier (1913, p. 73) on Arctic and sub-Arctic species of Nymphon.

\section{NYMPHON TURRITUM, new species}

Figure $33, g-k$

Description.-Body not so elongated as usual among members of the genus; lateral processes as long as or longer than segment of the body is wide, well separated. Proboscis long, cylindrical, withcut markings or ridges, somewhat ventrally inclined. Cheliferi well developed, the first segment or scape as long as proboscis and slightly bowed outward; hand or second segment shorter and heavier than first segment and inclined toward mouth, both preceding segments quite well clothed with hair and occasional spines; fingers very short and stout for member of this genus; immovable finger a little shorter than movable finger, both densely armed with long teeth along inner margin. Palpi with origin lateral to cheliferi, first segment very short, second and third long and slender, third a little longer than second and terminating in a well-developed ventrally curving spine and a circlet of hairs; segments 4 and 5 shorter, well clothed with hairs.

First segment with reck short and thick, greatly expanded at distal end for attachment of cheliferi and palpi, this part being heavier than any other portion of body. Eye tubercle directly dorsal to anterior part of first segment, which bears ovigera, very slender, tall, turret-shaped, very pointed at apex; eyes small, basal. In female paratype, eyes large and elongated, and eye tubercle slenderer than in holotype.

Ovigera attached directly in front of anterior pair of walking legs. First segment very short, second and third a little longer and heavier and almost equal in size; fourth and fifth very long and nearly equal in length; sixth much shorter but longer than second and third; seventh to tenth forming a curve and slenderer than preceding segments; seventh shorter than sixth and armed ventrally with a row of about 16 toothed spines; eighth a little shorter than seventh, armed with about 12 spines; ninth about equal in length to eighth, armed ventrally with about 9 spines; tenth almost equal to eighth and ninth, armed with about 12 ventral spines; claw very nearly as long as segment 10 , slender, armed ventrally with spinelike teeth. 


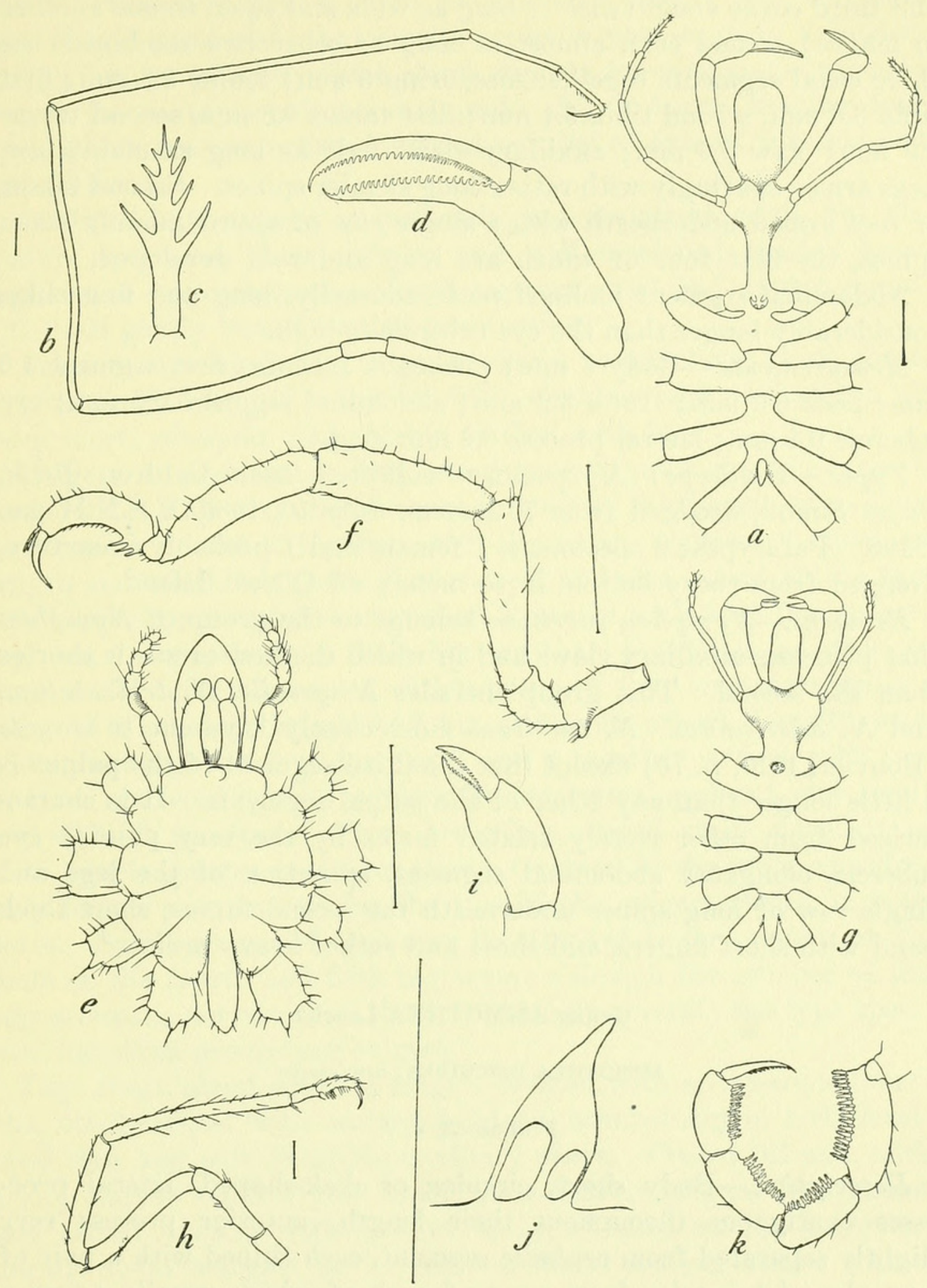

FIGURE 33.-NEW SPECIES OF NYMPHON AND AMMOTHEA

$a-d$, Nymphon solitarium: $a$, Body; $b$, leg; $c$, spine from oviger; $d$, chela of chelifer.

$e, f$, Ammothea discoidea: $e$, Body ; $f$, leg.

$g-k$, Nymphon turritum: $g$, Body; $h$, leg; $i$, chela ; $j$, eye tubercle ; $k$, tip of oviger.

Lines drawn beside figures each represent $1 \mathrm{~mm}$. 
Legs very long but not so long or slender as in $N$. solitarium; first and third coxae about twice as long as wide and equal to one another in length; second coxa almost as long as other two combined, the three coxal segments together measuring $3 \mathrm{~mm}$; femur $3.8 \mathrm{~mm}$; first tibia $3.6 \mathrm{~mm}$, second tibia $5.4 \mathrm{~mm}$; first tarsus $0.8 \mathrm{~mm}$, second tarsus $0.9 \mathrm{~mm}$; claw $0.6 \mathrm{~mm}$; auxiliary claws half as long as main claw. Legs armed sparingly with rather long slender spines. Second tarsus or foot armed underneath with a single row of approximately seven spines, the first four of which are long and well developed.

Abdominal segment inclined posterodorsally, long and fingerlike, considerably longer than the eye tubercle is high.

Measurements.-Body $5 \mathrm{~mm}$; proboscis $1.2 \mathrm{~mm}$; first segment 1.6 $\mathrm{mm}$; neck $0.9 \mathrm{~mm}$; trunk $3.2 \mathrm{~mm}$; abdominal segment $0.6 \mathrm{~mm}$; eye tubercle $0.4 \mathrm{~mm}$; lateral process $0.6 \mathrm{~mm}$ long.

Types.-Holotype: A specimen collected near Caldron Rock, Puget Sound, dredged from 70 meters, July 10, 1935, U.S.N.M. no. 71498. Paratypes: 2 specimens, 1 female and 1 probably immature, dredged from rocky bottom in 50 meters off O'Neal Island.

Remarles.-Nymphon turritum belongs to the group of Nymphon that possesses auxiliary claws and in which the first tarsus is shorter than the second. This group includes $N$. gracile, $N$. tridentatum, and $N$. adareanum. $N$. turritum most closely keys out to gracile (Bouvier, 1913, p. 73) except that the third segment of the palpus is a little longer than any other of the palpal segments. It is characterized from other closely related forms by the very pointed eye tubercle, elongated abdominal segment, spination of the legs and single row of long spines underneath the second tarsus, short thick hand with short fingers, and short and rather heavy neck.

\section{Genus AMMOTHEA Leach}

\section{AMMOTHEA DISCOIDEA, new species}

Figure $33, e, f$

Description.-Body short, circular or disk-shaped, lateral processes contiguous throughout their length, anterior process very slightly separated from cephalic segment, each tipped with a pair of laterodorsal tubercles from apex of each of which usually arises a short stiff bristle; abdominal process long, slender, reaching at least to distal end of first coxal segment of posterior legs or even farther.

Proboscis long, heavy, over half as long as trunk, thickest in middle, tapering a little to anterior end, which is blunt, terminating in mouth surrounded by three lips, one dorsomedian and two lateroventral. 
The anterior or cephalic part without neck, widened anteriorly and ending on each side in a small protuberance tipped with a bristle, like lateral processes. Anteriorly, cephalic part bearing a moderately high eye tubercle, which slants slightly forward and is rounded except for a very small pointed peak. Eye tubercle bearing four eyes, which are somewhat elongated parallel to axis of tubercle and are all basal.

Cheliferi half as long as proboscis; not chelate in adult, but immature specimens show definite and well-developed chelae; basal segment or scape elongate; second segment short and almost round. Cheliferi gently bowed toward one another.

Palpi 8-segmented; first segment short, second long, third short, fourth equal in length to second; fifth, sixth, seventh, and eighth all very short, subequal, and thickly clothed with hair.

Ovigera 10-segmented; first two segments quite stout, not much longer than wide and almost equal in length; third segment as long as segments 1 and 2 together and slenderer; segment 4 equal in length and width to 3 , somewhat curved, and also armed with a few small spines; segment 6 shorter than 5 , armed with very few spines; segment 7 very short, a little heavier than preceding, as wide as long, on its outer side armed with a group of four long stout spines; segment 8 equal in length to 7 but slenderer, armed dorsally with one spine; segment 9 as long as 7 and 8 together, armed with two or three scattered spines; segment 10 or terminal segment very small and difficult to separate from preceding, armed at its termination with two large spines but no claw. Ovigera in the male considerably longer than in female; the tips of the ovigera curled in both sexes. Small groups of eggs may be attached to the ovigera of the male on the fourth and fifth segments; although the number of the egg groups is not constant, there are usually several; the type specimen has seven groups per ovigera.

Legs short, about equal in length, covered with microscopic tubercles, stout, armed with scattered spines, terminating in well-developed claw and pair of strong auxiliary claws. Coxa I $0.5 \mathrm{~mm}$, with a long narrow tubercle that is not quite half so long as the segment and armed distally with a short spine, situated on the posterior, dorsal, distal margin; on its anterior distal margin armed with a small tubercle from which two or three spines arise, as wide as long; coxa II $0.7 \mathrm{~mm}$, armed on both sides with several spines; coxa III $0.5 \mathrm{~mm}$; femur $1.5 \mathrm{~mm}$, heavier from center to tip, especially swollen in female, armed distally with a short protuberance and spine; tibia I $1.4 \mathrm{~mm}$, armed dorsally with several short spines; tibia II, $1.3 \mathrm{~mm}$, armed dorsally with numerous short spines; tarsus I very short, 
about $0.2 \mathrm{~mm}$ and very slender, armed distally underneath with several spines; tarsus II stout, curved ventrally, $0.7 \mathrm{~mm}$ long, armed dorsally with a row of short spines, ventrally in proximal part armed with three or four heavy curved spines, distally with several small spines; claw $0.3 \mathrm{~mm}$ long, curved, untoothed; auxiliary claws slender but over half as long as claw. Genital apertures of male occur on distinct high tubercles on ventral distal margins of second coxae of two posterior pairs of legs; genital apertures of female occur on slightly swollen areas in a position similar to male on all four pairs of legs.

Abdominal process slender, cylindrical, pointing posteriorly but slightly bent upward, about three-fourths as long as proboscis; armed near tip with a few spines.

Immature specimens possess well-developed chelae and have been found ranging in size from specimens only half as large as mature specimens to fully grown specimens. Among smaller individuals the ovigera are entirely undeveloped and are indicated only by a bud in front of anterior pair of walking legs; in large specimens ovigera almost as complete as in mature females. It seems impossible to distinguish males and females among immature specimens.

Considerable variation is noted in the external appearance of individuals of Ammothea discoidea, owing to differing stages of ecdysis; specimens that had not recently molted when collected possess a tougher integument and stiffer and more visible spines than those that had just molted. The living animal varies from a deep pink to white; preserved specimens lose the pink color and vary from $\tan$ to white.

Measurements.-Body, including proboscis, $2.8 \mathrm{~mm}$; proboscis 1.1 $\mathrm{mm}$; trunk $1.1 \mathrm{~mm}$; abdominal segment $0.7 \mathrm{~mm}$; lateral process 0.5 $\mathrm{mm}$ long; eye tubercle $0.25 \mathrm{~mm}$ high.

Types.-Holotype: Male specimen collected with a group of males, females, and immature specimens dredged south of McNeils Island, Puget Sound, July 24, 1934, U.S.N.M. no. 71500. Paratypes: Males, females, and immature specimens dredged off Fosdick Point, Puget Sound, July 1935; immature and female specimens dredged off Blake Island, July 8, 1935; males, females, and immature specimens dredged off Lake Hancock, August 10, 1935; males, females, and immature specimens dredged between McNeils Island and Bahl Passage, July 8, 1935; specimens from off Caldron Rock (70 meters), July 10, 1935; females dredged off Vashon Point, July 24, 1934; immature specimens dredged off Fosdick Point, July 23, 1934; males, females, and immature specimens dredged from 40 meters off McNeils Island and Bahl Passage.

Remarks.-Ammothea discoidea is most nearly related to A. latifrons Cole (1904, p. 263), a species that occurs around Unalaska and 
the Pribilof Islands ${ }^{3}$; it agrees with latifrons in the sexual characters and in possessing the long, well-developed cheliferi, but differs notably in the shorter abdomen and the small size. It differs from the description of $A$. longicaudata Stimpson (1864, p. 159) from Puget Sound in having only eight segments in the palpi instead of nine and in its small size. Stimpson's description gives very few specific characters and is compiled from a single immature specimen, which should probably be placed in the genus Ammothella because of the 9-segmented palpi; Ammothella longicaudata (Stimpson) has not been collected in recent years.

A. discoidea is found in large numbers among hydroids of certain localities. Its limited distribution seems quite unaccountable at the present time. It has been collected only within a small range in the central part of Puget Sound off McNeils Island.

\section{AMMOTHEA ALASKENSIS Cole}

Ammothea alaskensis Cole, Harriman Alaska Expedition, vol. 10, p. 266, pl. 12, fig. 4 ; pl. 17, figs. 4-12, 1904.

One female specimen found off Lake Hancock, Puget Sound, July 8, 1935, dredged from 60 meters along with many specimens of $A$. discoidea. It measures only $2 \mathrm{~mm}$ rather than nearly $3 \mathrm{~mm}$, the eye tubercle is a little larger than that figured by Cole, and the abdomen is not so heavily spined. In other respects the specimen agrees so closely with Cole's description that these differences are to be overlooked until more material is available to study the variation consistent with the species.

\section{Genus PHOXICHILIDIUM Edwards}

\section{PHOXICHILIDIUM FEMORATUM (Rathke)}

Nymphon femoratum Rathke, Naturh. Selsk. Skrifter, vol. 5, p. 201, 1799. Phoxichilidium femoratum Cole, Harriman Alaska Expedition, vol. 10, p. 283, pl. 13 , fig. 10 ; pl. 24 , figs. $1-5,1904$.

Two females dredged south of McNeils Island, July 24, 1934; females and 3 immature specimens dredged between Shaw Island and Turn Rock, July 1, 1935; 1 female dredged from 60 meters off Lake Hancock, July 10, 1935; 1 male with eggs dredged in Hoods Canal, April 27, 1934; 1 male dredged from 70 meters off Caldron Rock, July 10, 1935.

These specimens differ considerably in size, 3.8 to $2.5 \mathrm{~mm}$. Two of the males possess ovigers in which there is an indication of a sixth segment; the wall of this is not entirely complete and seems to be inarticulate.

${ }^{3}$ Schmitt (1934, p. 69), however, records this species from Monterey Bay, Calif. 


\section{LITERATURE CITED}

BOUvier, Eugìne Louis.

1913. Pycnogonides du Pourquoi Pas? Duexième Expédition Antarctique Française (1908-1910), 169 pp., 109 figs.

Cole, Leon JacoB.

1904. Pyenogonida of the west coast of North America. Harriman Alaska Expedition, vol. 10, Crustacea, pp. 249-330, 16 pls.

Hall, HaRry V. M.

1913. Pycnogonida from the coast of California, with descriptions of two new species. Univ. California Publ. Zool., vol. 11, no. 6, pp. 127-142, 2 pls.

HODGSON, T. V.

1907. Pycnogonida. National Antarctic Expedition, 1901-1904, vol. 3, Zoology and Botany, 72 pp., 10 pls.

Schimkewitsch, Vladimir.

1913. Ein Beitrag zur Klassifikation der Pantoden. Zool. Anz., vol. 41, pp. 597-615.

Schmitt, Waldo Lasalle.

1934. Notes on certain pycnogonids including descriptions of two new species of Pycnogonum. Journ. Washington Acad. Sci., vol. 24, no. 1 , pp. 61-70, 1 fig.

Stimpson, William.

1864. Description of new species of marine Invertebrata from Puget Sound collected by the naturalists of the North-west Boundary Commission, A. H. Campbell, Esq., commissioner. Proc. Acad. Nat. Sci. Philadelphia, 1864, pp. 153-161. 


\section{$2 \mathrm{BHL}$ Biodiversity Heritage Library}

Exline, Harriet. 1936. "Pycnogonids from Puget Sound." Proceedings of the United States National Museum 83(2991), 413-422.

https://doi.org/10.5479/si.00963801.83-2991.413.

View This Item Online: https://www.biodiversitylibrary.org/item/32866

DOI: https://doi.org/10.5479/si.00963801.83-2991.413

Permalink: https://www.biodiversitylibrary.org/partpdf/9020

\section{Holding Institution}

Smithsonian Libraries

\section{Sponsored by}

Smithsonian

\section{Copyright \& Reuse}

Copyright Status: NOT_IN_COPYRIGHT

Rights: https://www.biodiversitylibrary.org/permissions/

This document was created from content at the Biodiversity Heritage Library, the world's largest open access digital library for biodiversity literature and archives. Visit BHL at https://www.biodiversitylibrary.org. 